\title{
Reconstruction of Midface Defects with the Facial Artery Perforator Flap: A Review of the Literature
}

\author{
Murat Sarıcı, ${ }^{1}$ Ahmet Adnan Cırık,, Gaye Taylan Filinte,, Tunç Tunçbilek
}

\footnotetext{
'Department of Plastic Surgery University of Health Sciences Kartal Dr. Lütfi Kırdar Training and Research Hospital, Istanbul, Turkey 2Department of Otorhinolaryngology, University of Health Sciences

Ümraniye Training and Research Hospital, İstanbul, Turkey

Submitted: 20.11.2017 Accepted: 27.11.2017

Correspondence: Gaye Taylan Filinte, Sağlık Bilimleri Üniversitesi Kartal Dr. Lütfi Kırdar Eğitim ve Araştırma Hastanesi, Plastik Cerrahi Kliniği, İstanbul, Turkey

E-mail: gayetaylan@yahoo.com

E-mail: gayetaylan@yahoo.com

Keywords: Facial artery; midface; perforator flap.
}

\begin{abstract}
Objective: Defects of the nasal, perinasal, and infraorbital areas usually develop after trauma or tumoral excision. The key points of reconstruction of these areas are achieving a good color match and tissue compatibility, avoiding or minimizing functional deficits, and preventing disfigurement in the surrounding tissue. This study is a review of midfacial defects reconstructed with a facial artery perforator flap.
\end{abstract}

Methods: Nineteen patients were operated on for midfacial tumoral masses between 20082017. After excision of the lesion with the appropriate surgical margins, the resulting defects were reconstructed with facial artery perforator flaps. Recovering the anatomical and functional structure of the area or avoiding deterioration was the goal. In order to avoid ectropion, flaps were anchored to the periosteum when the lower eyelid was involved. All flap donor sites were primarily repaired.

Results: In I patient, venous insufficiency was observed, and in another, hematoma and ecchymosis developed, but flap failure did not occur. A trap door deformity was observed in 2 flaps. The patients were satisfied with the aesthetic and functional outcomes.

Conclusion: The facial artery perforator flap is a good option for reconstruction of midface defects because it is elevated in a single stage, it provides freedom to design and transfer, and the donor site can be primarily closed.

\section{INTRODUCTION}

Basal cell or squamous cell carcinoma is frequently seen on the midface as a result of the cumulative effect of exposure to sunlight. ${ }^{[l]}$ Defects that can be primarily repaired when localized in other regions of the body require extremely sophisticated reconstruction procedures when they occur on the midface. The main reasons for a highly innovative approach include concern to prevent aesthetic or functional impairment, and the inability to perform primary closure due to tensile forces between the edges of the defect. ${ }^{[2]}$

Local, regional, and distant flaps have been used in the reconstruction of this region; however, local flaps have generally been preferred because of better color match and tissue compatibility, and ease in transfer. ${ }^{[3]}$
With developments in perforator flap reconstruction and better understanding of the anatomy of the facial artery, surgeons now tend to use transportable perforator flaps, which easily coapt the defect. ${ }^{[4,5]}$

The aim of this study was to enhance understanding of planning details in the use of facial artery perforator flaps, and to provide a patient series featuring midfacial defects repaired using these flaps.

\section{MATERIAL AND METHODS}

Between 2008 and 2017, 19 patients were operated on due to midfacial tumoral masses (Table I). The lesions were excised with the appropriate surgical margins, and the defects created were repaired using perforator flaps. 
Table I. Details of the patients and surgeries performed

\begin{tabular}{|c|c|c|c|c|c|c|}
\hline Patient no. & Age & Gender & Pathology & Location & Defect size $(\mathrm{cm})$ & Operation \\
\hline I & 62 & Female & $\mathrm{BCC}$ & Right infraorbital & $2 \times 2$ & Propeller $180^{\circ}+\mathrm{advancement}$ \\
\hline 2 & 44 & Female & SCC & Right medial infraorbital & $2.5 \times 2$ & Propeller $180^{\circ}$ \\
\hline 3 & 66 & Female & $\mathrm{BCC}$ & Nasal dorsum I/3 midpoint & $2 \times 2$ & Propeller $100^{\circ}-120^{\circ}$ \\
\hline 4 & 58 & Female & $\mathrm{BCC}$ & Right nasal ala & $1.5 x \mid .5$ & Propeller $100^{\circ}-120^{\circ}$ \\
\hline 5 & 56 & Female & $\mathrm{BCC}$ & Right infraorbital & $2 \times 3$ & Propeller $180^{\circ}+\mathrm{advancement}$ \\
\hline 6 & 41 & Male & $\mathrm{BCC}$ & Right nasal ala & $1.5 \times 2$ & Propeller $100^{\circ}-120^{\circ}$ \\
\hline 7 & 70 & Male & SCC & Nasal dorsum I/3 upper left & $1.5 \times 2$ & $\begin{array}{l}\text { Transposition through } \\
\text { subcutaneous tunnel }\end{array}$ \\
\hline 8 & 52 & Female & $\mathrm{BCC}$ & Left nasofacial crease & $2 \times 2$ & Advancement \\
\hline 9 & 48 & Female & $\mathrm{BCC}$ & Left medial infraorbital & $1.5 \times 2$ & Propeller $180^{\circ}+$ advancement \\
\hline 10 & 58 & Male & $\mathrm{BCC}$ & Nasal dorsum lower $1 / 3$ & $2 \times 2$ & $\begin{array}{l}\text { Transposition through } \\
\text { subcutaneous tunnel }\end{array}$ \\
\hline II & 46 & Female & $\mathrm{BCC}$ & Right upper lip & $2 \times 2$ & $\begin{array}{l}\text { Transposition through } \\
\text { subcutaneous tunnel }\end{array}$ \\
\hline 12 & 51 & Female & $\mathrm{BCC}$ & Nasal dorsum lower $1 / 3$ & $1.5 \times 2$ & $\begin{array}{l}\text { Transposition through } \\
\text { subcutaneous tunnel }\end{array}$ \\
\hline 13 & 62 & Female & $\mathrm{BCC}$ & Right nasal ala & $1.5 \times 1.5$ & Propeller $100^{\circ}-120^{\circ}$ \\
\hline 14 & 68 & Female & $\mathrm{BCC}$ & Right infraorbital & $3 \times 3$ & Propeller $180^{\circ}+$ advancement \\
\hline 15 & 63 & Female & $\mathrm{BCC}$ & Nasal dorsum lower $2 / 3$ & $2.5 \times 2$ & Propeller $100^{\circ}-120^{\circ}$ \\
\hline 16 & 58 & Female & $\mathrm{BCC}$ & Nasal dorsum lower $1 / 3$ & $1.5 x \mid .5$ & Propeller $100^{\circ}-120^{\circ}$ \\
\hline 17 & 47 & Male & $\mathrm{BCC}$ & Left nasal ala & $1.5 \times 2$ & Propeller $100^{\circ}-120^{\circ}$ \\
\hline 18 & 56 & Female & SCC & Nasal dorsum I/3 middle right & $2 \times 2$ & Propeller $100^{\circ}-120^{\circ}$ \\
\hline 19 & 64 & Male & $\mathrm{BCC}$ & Nasal dorsum lower I/3 & $2 \times 2$ & Propeller $100^{\circ}-120^{\circ}$ \\
\hline
\end{tabular}

BCC: Basal cell carcinoma; SCC: Squamous cell carcinoma.

\section{Surgical technique}

The dimensions of the defects following tumor excision were measured, and the appropriate perforator flaps for the closure of these defects were designed. For the upper lip, nasal dorsum, perinasal area, and infraorbital region, flaps were obtained from the nasolabial sulcus. The periphery of the flap was incised until the subcutaneous tissue was reached. Excluding those transferred to the upper lip, the flaps were elevated from the caudal direction toward the cranial plane. In cases of restoration of upper lip defects, flaps were elevated from the suprafacial plane, from the cranial direction down to the caudal. Meticulous dissection was performed around the region planned for the pedicle flap, and the appropriate area for the perforator flap was determined. A small quantity of soft tissue was left around the pedicle in order to avoid problems inherent to venous return and to protect the very thin pedicle from tensile forces. The flaps were coapted to the defect using advancement, transposition passing through a subcutaneous tunnel, or rotational maneuvers. In order to avoid the formation of ectropion, flaps designed especially for infraorbital region defects were anchored to the medial canthal region or the periosteum of the infraorbital rim with I or 2 sutures. The flap donor sites were primarily repaired.

\section{RESULTS}

The median follow-up period of the patients was 23 months. During the early postoperative period, signs of venous insufficiency were observed in I patient; however, it regressed without the need for additional intervention on the postprocedural fourth day. No instance of hemato$\mathrm{ma}$, infection, wound site dehiscence, or flap failure, either partial or total, was seen. During the late postoperative follow-up period, no prominent donor site scar was observed. A trap door deformity developed in 2 patients. No recurrence was seen during the follow-up period. A satisfactory cosmetic and functional outcome was obtained in all patients (Fig. I). Ectropion or retraction of the lower 


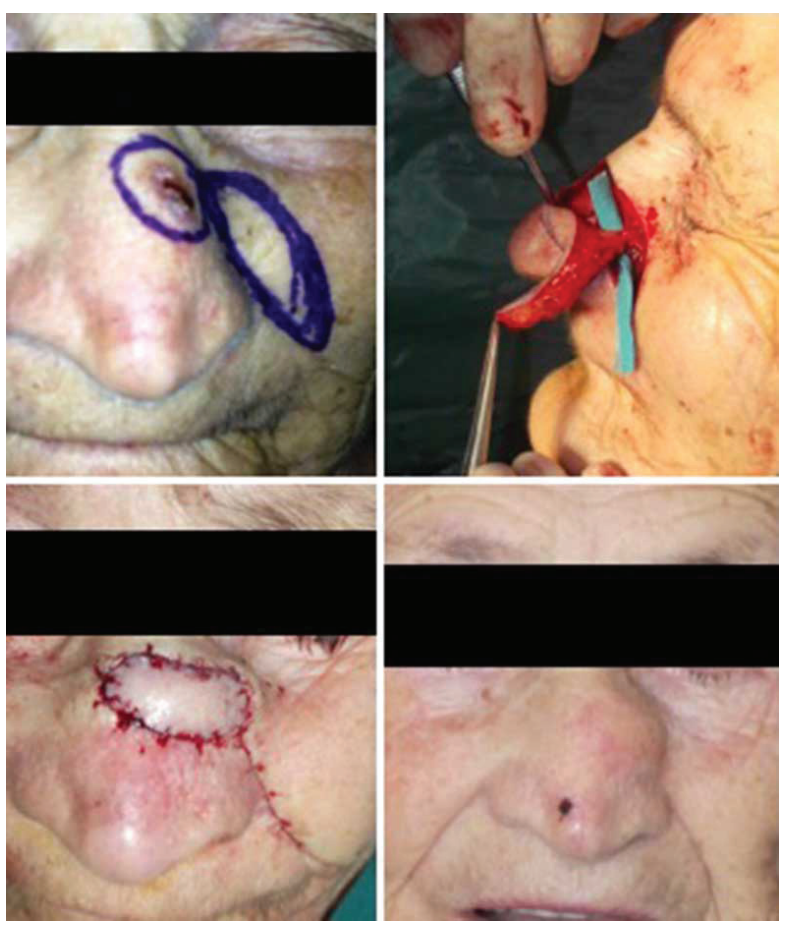

Figure 1. Right infraorbital skin tumor, before and 34 months after the operation.

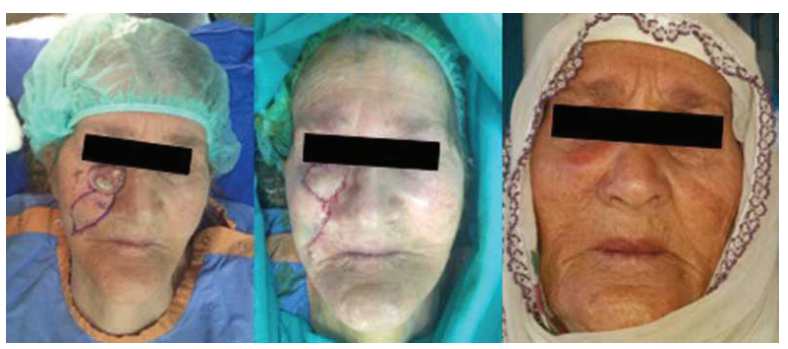

Figure 2. Skin tumor of the nasal dorsum, before and 7 months after the operation.

lid did not occur in patients who underwent infraorbital region reconstruction (Fig. 2).

\section{DISCUSSION}

The midfacial region is the focus of significant social attention. ${ }^{[6]}$ Therefore, obtaining a cosmetically acceptable and functional outcome may be as important as eradication of the tumor. ${ }^{[1,3,7]}$ Primary repair is possible for the reconstruction of small defects; however, different surgical procedures are needed when defects are larger. The use of local flaps allows for the best color match and assurance of tissue compatibility. ${ }^{[2,8,9]}$

For small and medium-sized defects of the dorsum nasi and the infraorbital region, the best alternative is the use of nasolabial skin as a flap donor site. However, this donor site, which may be used as a rotational or transpositional flap, has disadvantages as well, including a limited rotation arc, potential sequela of "dog ear deformity" on the flap base, and the requirement of a secondary surgery. ${ }^{[10]}$

Ersoy and Aköz ${ }^{\left[{ }^{\prime I}\right]}$ especially emphasized the appearance of this region on an individual's social life, and used a nasolabial V-Y advancement flap for the reconstruction of midfacial defects. They reported that use of a flap in this region might be preferable to reconstruction with a graft.

Taylor and Palmer ${ }^{[12]}$ mapped body perforators in 1987 , and Kroll[13] used the term "perforator flap" in 1988. Perforator flaps are now widely used in many regions of the world, thanks to the better mobilization and elevation of flaps with large diameters over perforating vessels they provide. Furthermore, it allows for the formation of freestyle facial flaps. Hofer et al. ${ }^{[14]}$ subsequently described facial artery perforating vessels in detail, and facial artery perforator flaps have since frequently been used in the reconstruction of perioral defects.

Elevation of the nasolabial region as a perforator flap minimizes the disadvantages of a classic nasolabial flap, and improved aesthetic and functional outcomes can be obtained with a freestyle facial flap design and easy coaption of the defect.

The main artery and perforating vessel lying between the oral commissure and the medial canthus could not be clearly identified because the facial artery courses very close to the facial skin. ${ }^{[13,14]}$ However the midfacial region is very rich in perforating vessels, so with meticulous dissection, a suitable perforating artery can be found. ${ }^{[15,16]}$

The problem of venous insufficiency, which can develop in perforator flaps, was also observed in one of our patients. $^{[17]}$ A small quantity of soft tissue left around the flap after fixation of the flap pedicle usually prevents the development of venous insufficiency. This soft tissue left around the flap protects this very thin flap pedicle from tensile forces, and prevents blood flow arrest caused by pressure on the pedicle. ${ }^{[12]}$ Another potentially unfavorable outcome is prolongation of operative time due to the meticulous dissection of the pedicle. ${ }^{[5,18]}$ However as experience accumulates, flap elevation time may be reduced to conventional local flap elevation time.

\section{Conclusion}

In the repair of midfacial defects, the results obtained using facial artery perforator flaps can be at least as good as those achieved with established local flaps. In addition, they allow for greater freedom to design, and they can be easily rotated $\geq 180^{\circ}$ to coapt the defect. They are very functional flaps with multiple advantages. For example, if an intact cutaneous area exists between the defect and the donor site, they can be easily transferred to the defect site through a subcutaneous tunnel without leaving any disfigurement. 


\section{Ethics Committee Approval}

The approval of the local Ethics Committee was obtained. Informed Consent

Approval was obtained from the patients.

Peer-review

Internally peer-reviewed.

Authorship Contributions

Concept: M.S., A.A.C.; Design: M.S., A.A.C.; Data collection \&/or processing: M.S., A.A.C.; Analysis and/or interpretation: M.S., A.C., G.T.F.; Literature search: M.S., A.A.C., T.T.; Writing: M.S., A.A.C., G.T.F.; Critical review: G.T.F., T.T.

\section{Conflict of Interest}

None declared.

\section{REFERENCES}

1. D’Arpa S, Cordova A, Pirrello R, Moschella F. Free style facial artery perforator flap for one stage reconstruction of the nasal ala. J Plast Reconstr Aesthet Surg 2009;62:36-42. [CrossRef]

2. Pepper JP, Baker SR. Local flaps: cheek and lip reconstruction. JAMA Facial Plast Surg 2013;15:374-82. [CrossRef]

3. Salgarelli AC, Bellini P, Multinu A, Magnoni C, Francomano M, Fantini F, et al. Reconstruction of nasal skin cancer defects with local flaps. J Skin Cancer 2011;2011:181093. [CrossRef]

4. Kim SW, Kim YH, Kim JT. Angular artery perforator-based transposition flap for the reconstruc-tion of midface defect. Int J Dermatol 2012;51:1366-70. [CrossRef]

5. Brunetti B, Tenna S, Aveta A, Segreto F, Persichetti P. Angular artery perforator flap for recon-struction of nasal sidewall and medial canthal defects. Plast Reconstr Surg 2012;130:627e-8e. [CrossRef]
6. Meara DJ. Acquired defects of the nose and naso-orbitoethmoid (NOE) region. Oral Maxillofac Surg Clin North Am 2013;25:131-49.

7. Sohn WI, Choi JY, Seo BF, Jung SN. Reconstruction of nasal ala with nasolabial perforator flap after cancer removal. Head Neck Oncol 2012;4:83.

8. Schubert J. Local flaps for the closure of facial defects. HNO 2013;61:433-46. [CrossRef]

9. Wheatley MJ, Smith JK, Cohen IA. A new flap for nasal tip reconstruction. Plast Reconstr Surg 1997;99:220-4. [CrossRef]

10. El-Marakby HH. The versatile naso-labial flaps in facial reconstruction. J Egypt Natl Canc Inst 2005;17:245-50.

11. Ersoy B, Aköz T. Tümör rezeksiyonu sonrası oluşan orta yüz defektlerinin onarıminda nazola-bial V-Y ilerletme flebinin kullanımı. Maltepe Tip Dergisi 2016;8:1-4.

12. Taylor GI, Palmer JH. The vascular territories (angiosomes) of the body: experimental study and clinical applications. Br J Plast Surg 1987;40:113-41. [CrossRef]

13. Kroll SS, Rosenfield L. Perforator-based flaps for low posterior midline defects. Plast Reconstr Surg 1988;81:561-6. [CrossRef]

14. Hofer SO, Posch NA, Smit X. The facial artery perforator flap for reconstruction of perioral de-fects. Plast Reconstr Surg 2005;115:9961003. [CrossRef]

15. Ng ZY, Fogg QA, Shoaib T. Where to find facial artery perforators: a reference point. J Plast Reconstr Aesthet Surg 2010;63:2046-51.

16. Qassemyar Q, Havet E, Sinna R. Vascular basis of the facial artery perforator flap: analysis of 101 perforator territories. Plast Reconstr Surg 2012;129:421-9. [CrossRef]

17. Kannan RY, Mathur BS. Perforator flaps of the facial artery angiosome. J Plast Reconstr Aes-thet Surg 2013;66:483-8. [CrossRef]

18. Demirseren ME, Afandiyev K, Ceran C. Reconstruction of the perioral and perinasal defects with facial artery perforator flaps. J Plast Reconstr Aesthet Surg 2009;62:1616-20. [CrossRef]

\section{Fasiyal Arter Perforatör Flep ile Orta Yüz Bölgesi Defektlerinin Onarımı: Literatürün Gözden Geçirilmesi}

Amaç: Nazal, perinazal ve infraorbital defektleri genellikle travma ve tümör eksizyonu sonrası ortaya çıkar. Bu bölgelerin rekonstrüksiyonunda iyi renk ve doku uyumunun yanında fonksiyonel kaybın olmaması veya en aza indirgenmesi ve çevre yapılarda bozulma yaratmaması da önemli noktalardır. Bu yazıda fasiyal arter perforatör flep ile rekonstrüksiyonu yapılmış orta yüz bölge defektleri sunulmaktadır.

Gereç ve Yöntem: 2008 ile 2017 yılları arasında 19 hasta orta yüz bölgesindeki tümöral kitleler nedeniyle ameliyat edildi. Lezyonlar uygun cerrahi sınırlar ile eksize edildikten sonra ortaya çıkan defektler fasiyal arter perforatör flepler ile onarıldı. Her bölgenin rekonstrüksiyonunda o bölgenin anatomik yapılarının ve fonksiyonlarının bozulmaması veya yeniden sağlanmasına özen gösterildi. Alt göz kapağında ektropiyonu engellemek için flep periosta sabitlendi. Tüm flep donör alanları primer onarıldı.

Bulgular: Bir hastada venöz yetmezlik, bir hastada hematom ve ekimoz gelişti ancak bunlara rağmen bir flep kaybı yaşanmadı. Ayrıca iki hastada fleplerde trap door deformitesi gelişti. Bu hastalar dışında hastaların tamamı estetik ve fonksiyonel açıdan sonuçlardan memnun kaldı.

Sonuç: Orta yüz bölge defektlerinin rekonstrüksiyonunda fasiyal arter perforatör flebi, tek seanslı olması cerraha flep dizaynı ve taşınmasında serbestlik ve rahatlık sağlaması ve donör alanın primer kapatılarak kabul edilebilir görünüme kavuşması ile çok kullanışlı bir seçenektir.

Anahtar Sözcükler: Fasiyal arter; orta yüz; perforatör flep. 